\title{
Physiological responses of mussel larvae Mytilus edulis to environmental hypoxia and anoxia
}

\author{
W. X. Wang, J. Widdows \\ Plymouth Marine Laboratory, Prospect Place, The Hoe, Plymouth PL1 3DH, United Kingdom
}

\begin{abstract}
Anoxia tolerance of Mytilus edulis larvae, expressed in terms of median mortality time, increased from $14.7 \mathrm{~h}$ in early prodissoconch larvae $(106 \mu \mathrm{m})$ to $38.7 \mathrm{~h}$ in later veliconch larvae $(224 \mu \mathrm{m})$. Both embryos and early prodissoconch larvae developed and grew normally at $P_{\mathrm{O}_{z}}$ values $\geq 3.16 \mathrm{kPa}$. Feeding activity by the early larval stages generally was maintained or even enhanced under hypoxic conditions $(\geq 3.16 \mathrm{kPa}$ ). In contrast, rates of feeding and growth by later stages were depressed at all hypoxic levels examined. Hypoxia had little influence on settlement behaviour of pediveliger larvae, but larvae developed their 'eye-spots' at a smaller size in such circumstances, indicating the uncoupling of growth and morphogenic processes under hypoxic stress. These physiological responses of mussel larvae were also supported by calorimetric and respirometric measurements of heat dissipation and oxygen uptake. Early larval stages were able to maintain their energy metabolism at reduced $P_{\mathrm{O}_{2}}$ (critical $P_{\mathrm{O}_{2}}=2 \mathrm{kPa}$ ), whereas later stages suppressed heat dissipation at moderate hypoxia. There was no significant anaerobic component of total energy expenditure by mussel larvae under hypoxic conditions above ca $1 \mathrm{kPa}$. Changes occurring during larval development resulted in a more oxygendependent metabolic rate above a critical larval size of 150 to $160 \mu \mathrm{m}$, presumably due to a decrease in surface area to volume ratio, and the secretion of the prodissoconch II shell, which may limit oxygen diffusion and uptake.
\end{abstract}

\section{INTRODUCTION}

Many estuaries, bays and shallow coastal waters exhibit periods of hypoxia and anoxia as a result of temperature and salinity stratification, often in conjunction with eutrophication and organic enrichment (e.g. Chesapeake Bay: Wright \& Phillips 1988; Kattegat, Western Sweden: Rosenberg \& Loo 1988; North Sea: Brockmann et al. 1988; Northern Adriatic Sea: Degobbis 1989). Such events coincide with periods of spawning and larval settlement by benthic invertebrates and appear to be a major factor influencing the structure and stability of marine benthic communities (Rosenberg \& Loo 1988). While marine benthic bivalve larvae are primarily distributed in the surface water during their early pelagic life, the majority are found in bottom waters as they develop into the later stages prior to settlement and metamorphosis (Thorson 1950 , Mileikovsky 1971). Consequently, they are likely to be subjected to these hypoxic and anoxic environments, which may ultimately affect the survival and growth of larvae, the recruitment of juveniles, and finally the structure and abundance of the adult population.
Several studies have examined the physiological responses of adult mussels Mytilus edulis to hypoxia and anoxia (Bayne 1971, 1975, Famme et al. 1981, Shick et al. 1986; for review see Bayne \& Newell 1983 and Shick et al. 1988). Nevertheless, little is known about the responses of the early planktotrophic larval phase of this species to hypoxia and anoxia. In $M$. edulis the duration of larval life ranges from 3 to more than $5 \mathrm{wk}$ before metamorphosis and settlement. During this period the larvae undergo considerable morphological, physiological, biochemical and behavioural changes (Bayne 1976, 1983). One of the aims of this study was to investigate the physiological responses of mussel larvae to reduced oxygen availability at various developmental stages, in order to assess the effects of environmental hypoxia and anoxia.

In a recent paper, Widdows et al. (1989) examined anoxia tolerance, ingestion activity, oxygen uptake and heat dissipation of the larvae and spat of Crassostrea virginica under normoxia, hypoxia and anoxia. One of the significant findings was that the early prodissoconch larvae are less affected by hypoxia in terms of their feeding and metabolic responses, but that the 
anoxia tolerance increases with larval development. In this study, we measured physiological processes including growth, feeding, oxygen uptake and heat dissipation of mussel larvae Mytilus edulis under normoxia, hypoxia and anoxia. Simultaneous microcalorimetry and respirometry were employed to quantify and partition total energy expenditure into aerobic and anaerobic components. Finally our aim was to interpret the energetic basis of the physiological processes of different larval stages in response to hypoxia.

\section{MATERIALS AND METHODS}

Spawning and rearing of larvae. Adult mussels Mytilus edulis were collected at neap tide level from Whitsand Bay, Cornwall, UK, in March 1989. Epifauna were scrubbed from their shells and the mussels were held in a system of recirculating and aerated seawater maintained at a temperature of $10 \pm 1.0^{\circ} \mathrm{C}$ and salinity of $31 \pm 1.0$ ppt. Mussels were continuously supplied with algal cells Phaeodactylum tricornutum. Groups of mussels (ca 10 individuals) were induced to spawn by initial exposure to air at ca $5^{\circ} \mathrm{C}$ for 3 to $4 \mathrm{~h}$ and then placement in $2 \mathrm{l}$ beakers containing membrane-filtered seawater $(0.45 \mu \mathrm{m})$ at $15^{\circ} \mathrm{C}$. After individuals had spawned, which usually occurred 3 to $4 \mathrm{~h}$ after reimmersion, they were removed from the beaker and the sperm and eggs were mixed. As soon as the first polar body appeared, the fertilised eggs were collected $(20$ $\mu \mathrm{m}$ mesh) and washed with filtered seawater (FSW) to remove excess sperm. The eggs were then transferred to 21 beakers and maintained at a density of ca 20 eggs $\mathrm{ml}^{-1}$ in FSW. During the course of larval development, larvae were initially fed Isochrysis galbana at a concentration of ca 30000 cells $\mathrm{ml}^{-1}$ and this increased to ca 50000 to 60000 cells $\mathrm{ml}^{-1}$ at the veliconch stage. The temperature and salinity during the culture period were $15^{\circ} \mathrm{C}$ and $31 \mathrm{ppt}$ respectively, and the seawater was replaced every $2 \mathrm{~d}$. The larval culture was gently aerated and held under a light:dark cycle of ca 12:12 h.

Before the experimental measurements, larvae representing a specific stage/size were sieved from the general culture with an appropriate mesh and resuspended in $100 \mathrm{ml} \mathrm{FSW}$. Only those larvae that were actively swimming in the water column were used for each experimental trial.

The relationships between larval shell length and weight were established over the size range from early prodissoconch larvae $(106 \mu \mathrm{m})$ to pediveliger stage (280 $\mu \mathrm{m})$. A known number of larvae were filtered onto preashed and pre-weighed glass fibre filters (Whatman $\mathrm{GF} / \mathrm{C}$ ) and washed with distilled water before being freeze-dried (overnight) and ashed $\left(450^{\circ} \mathrm{C}, 4 \mathrm{~h}\right)$. Filter and larval weights were determined using a Cahn
Model 4100 Electrobalance, Individual shell length measurements were made with a Kontron Image Analysis System connected to a Reichert-Jung Polyvar microscope with a calibrated graticule eyepiece. The established relationships are as follows:

$$
\begin{gathered}
\mathrm{DW}=1.94 \times 10^{-6} \mathrm{SL}^{2.486}(\mathrm{n}=7, \mathrm{r}=0.97) \\
\mathrm{AFDW}=6.95 \times 10^{-7} \mathrm{SL}^{2.573}(\mathrm{n}=7, \mathrm{r}=0.93)
\end{gathered}
$$

where DW = total dry weight in $\mu \mathrm{g} ;$ AFDW = ash-free dry weight in $\mu g_{i} \mathrm{SL}=$ shell length ( $\mu \mathrm{m}$; mean of 20 to 30 individuals); $n=$ number of samples, each based on 3 or 4 replicates of larvae from the same group. In each replicate larval number ranged between 50 to 300 (individuals) depending upon the stage/size.

Anoxia tolerance experiments. Experimental procedures for measuring the anoxia tolerance of larvae were given in Widdows et al. (1989). Two larval sizes (106 and $224 \mu \mathrm{m}$ shell length) were examined. Groups of 40 to 200 individuals (depending on size) were introduced into $5 \mathrm{ml}$ glass syringes. The seawater within each syringe was replaced with anoxic seawater $\left(\mathrm{N}_{2}\right.$ bubbling) from a large reservoir and was repeated 5 times, in order to attain as nearly as possible total anoxia ( $<0.2 \%$ of full air saturation). A filter holder with a mesh size of $53 \mu \mathrm{m}$ was attached to the syringe to retain the larvae during the process of water exchange. The partial oxygen pressures in the large reservoir and syringes were determined by an oxygen electrode (E5046) mounted in a thermostated cell and connected to a Radiometer oxygen meter and chart recorder. The electrode was calibrated with air-saturated water $(100 \%)$ and oxygen-free nitrogen gas or oxygen-zero solution (S4150 Radiometer Copenhagen).

All the syringes were sealed by inserting the stainless steel needle into a silicone stopper and then incubated in a glass desiccator purged by a stream of nitrogen gas. At intervals syringes were removed from the reservoir and anoxia confirmed with the oxygen electrode. The larvae within the syringe were then transferred to a small volume of seawater that was gently aerated for a period of at least $1 \mathrm{~h}$. The total number of larvae and the proportion surviving were counted on a Sedgewick-Rafter slide under a microscope. Only those which had a visible ciliary activity under the microscope were considered to be alive. Occasionally, a few syringes during the anoxia exposure were observed directly under the microscope, to establish whether the larvae were able to maintain their locomotory capability under anoxia.

Measurements of larval development, growth and settlement under hypoxic conditions. Embryos or lârvae were maintained under normoxia $(20.0 \pm 0.33 \mathrm{kPa})$ and 3 levels of hypoxia, $5.91 \pm 0.32,3.16 \pm 0.29$, and $1.38 \pm 0.19 \mathrm{kPa}$ (mean $\pm 2 \mathrm{SE}$ ). Each experimental condition consisted of a glass reservoir (2 l volume) 
containing FSW continuously bubbled with an appropriate mixture of $\mathrm{N}_{2}$ and $\mathrm{O}_{2}$ from a gas cylinder. The water flowed into 2 replicate experimental chambers (500 $\mathrm{ml}$ ) through gas-impermeable butyl-rubber tubing and out via a peristaltic pump. Each day, FSW was added to the reservoir and bubbled for 3 to $4 \mathrm{~h}$, during which time the peristaltic pump was stopped until the partial pressure of oxygen $\left(P_{\mathrm{O}_{2}}\right)$ in the reservoir reached the required oxygen level. $P_{\mathrm{O}_{2}}$ in the water flowing out of the experimental chamber was measured 1 or 2 times daily, by using an oxygen sensor connected to oxygen meter and chart recorder as described. Before the embryos or larvae were introduced into this system, the experimental chambers were filled with seawater at the appropriate oxygen concentration and water was pumped through the system for 8 to $12 \mathrm{~h}$, to reach a relatively steady state of $P_{\mathrm{O}_{2}}$.

Embryonic development during hypoxia. Adult mussels were induced to spawn and the eggs fertilised as described. Thirty minutes later when the first probe body appeared, the embryos were washed and concentrated into a small volume of FSW $(50 \mathrm{ml})$. After estimating its density, a known volume was introduced into each experimental chamber at a concentration of ca 20 embryos $\mathrm{ml}^{-1}$. The flow rate through the system was $37 \mathrm{ml} \mathrm{h}^{-1}$. At the end of exposure the number of developed prodissoconch larvae, abnormal embryos (i.e. having no velum or shell but actively swimming) and undeveloped eggs were quantified by counting three $5 \mathrm{ml}$ samples from each chamber using a Wild microscope. In addition, the shell lengths of 50 individual prodissoconch larvae from each condition were measured, if sufficient survived to the end of the experiment.

There were 2 experiments, each of different duration. One experiment was run for $60 \mathrm{~h}$, then all developed larvae and undeveloped embryos were returned to normoxic condition (full air saturation). The rate of shell growth of these 'recovery' larvae was measured over $3 \mathrm{~d}$ periods for $9 \mathrm{~d}$. Another experiment was run for $48 \mathrm{~h}$ and, after estimating the developmental rate in each $P_{\mathrm{O}_{2}}$ condition, the remaining larvae were maintained under the same hypoxic level for a further $14 \mathrm{~d}$ to observe the effects of hypoxia on later larval development and growth. In this experiment larval survival and shell length were monitored every $2 \mathrm{~d}$. The dead larvae were identified as those without ciliary activity when checked under the microscope.

Larval growth and development during hypoxia. Three larval sizes $(124,180,240 \mu \mathrm{m}$ shell length) were studied. The protocol for all measurements was identical to the experiment involving embryos. Larval density within each glass chamber ranged between 3 and 10 individuals $\mathrm{ml}^{-1}$ depending upon body size. System flow rates were 37,53 and $66 \mathrm{ml} \mathrm{h}^{-1}$ for the 124 .
180 and $240 \mu \mathrm{m}$ larvae respectively. The exposure period varied with each larval stage, ranging from 6 to $10 \mathrm{~d}$. Larval survival (not presented in the text) and growth (30 to 50 individuals) was monitored every other day by sampling three $5 \mathrm{ml}$ samples from each chamber.

After $6 \mathrm{~d}$ exposure to hypoxia, veliconch larvae (initial shell length $180 \mu \mathrm{m}$ ) were allowed to recover for a further $6 \mathrm{~d}$ under normoxic condition, to examine whether there was 'catch-up growth' following a period of growth suppression.

Mytilus edulis larvae develop 'eye-spots' at ca 250 to $270 \mu \mathrm{m}$ shell length (Pechenik et al. 1990, Wang unpubl.). Consequently larvae of $240 \mu \mathrm{m}$ shell length were exposed to hypoxia to determine the effect on both growth and developmental processes. Larval development was expressed as the percentage of individuals with 'eye-spots' within a sample of 100 to 200 larvae. This was checked every other day together with the shell length measurements (30 to 50 individuals). After $8 \mathrm{~d}$, when most larvae under both normoxia and moderate hypoxia had developed 'eye-spots', a few byssus filaments collected from adult mussels and cleaned with distilled water were introduced carefully into each chamber to provide a substratum for settlement. All experimental chambers were placed on a shaking table (rotation rate ca 52 cycles min $^{-1}$ ) providing water agitation inducive to larval settlement (Eyster \& Pechenik 1987). Three days later both larvae and filaments were collected on a 'Nitex' mesh $(150 \mu \mathrm{m})$ and the number attached firmly to the substratum (i.e. those not dislodged by a vigorous stream of water from a pipette: Eyster \& Pechenik 1987) was counted under the microscope. This was finally expressed as the settlement rate as the proportion of the total eyed larvae in each chamber.

Measurements of ingestion rate of larvae under hypoxia. The measurements of larval ingestion rates were performed in experimental apparatus similar to that described for the growth study, except for the volume of the glass chamber $(100 \mathrm{ml})$ and the flow rate $\left(70 \mathrm{ml} \mathrm{h}^{-1}\right)$. Four larval classes were measured during a period of 0 to $6 \mathrm{~d}$. The flagellate Isochrysis galbana was added to the seawater reservoir at a concentration of ca 20000 cells ml ${ }^{-1}$. Each seawater reservoir was continuously bubbled with an appropriate mixture of nitrogen and oxygen gas to maintain the $P_{\mathrm{O}_{2}}$ within the experimental apparatus. Larval density within each glass vial was 7 to 24 ind. $\mathrm{ml}^{-1}$ depending on body sizes. After transferring the larvae, the experimental chambers were filled with normoxic or hypoxic seawater from the reservoirs. The flow $\left(70 \mathrm{ml} \mathrm{h}^{-1}\right)$ was maintained for ca 3 $h$, stabilising the partial pressure of oxygen and allowing larvae to adjust to the ambient experimental conditions. Water from the chamber outflows was sampled, 
the algal cell concentrations counted using a Coulter Counter (Model D), and the partial pressure of oxygen measured with an oxygen sensor. The flow system was then stopped and all vials were held in total darkness to minimise the potential division of algal cells. Larvae were incubated in such a 'static' condition for a period of 3 to $6 \mathrm{~h}$, after which the final algal concentrations and $P_{\mathrm{O}_{2}}$ were measured. In each $P_{\mathrm{O}_{2}}$ group there was a 'blank' or control vial without larvae, reflecting any changes associated with algal cell concentrations during the incubation period. The flow of water through the system was resumed after completing the ingestion rate measurements. These measurements were repeated daily for up to $6 \mathrm{~d}$ of hypoxia depending on larval size $(114,150,180$ and $278 \mu \mathrm{m})$.

At the end of each exposure experiment, larval density was determined by taking five $5 \mathrm{ml}$ aliquots from each vial. A preliminary experiment established that there was little larval mortality during $2 \mathrm{~d}$ exposure under moderate hypoxia in such a flow-through system. However, there was significant mortality in the lower $P_{\mathrm{O}_{2}}$ levels when exposure was extended beyond $2 \mathrm{~d}$. In such circumstances we quantified larval density each day after the ingestion rate measurement and this was used to calculate the ingestion rate per individual larva accordingly.

At each $P_{\mathrm{O}_{2}}$ level there were 2 parallel experimental chambers and larval ingestion rates were expressed as the mean of both replicates ( \pm semi-range). Ingestion rates were calculated according to Sprung (1984):

$$
\begin{aligned}
& F=\frac{V}{n}\left(\frac{\ln C_{\mathrm{o}}-\ln C_{\mathrm{t}}}{t}-A\right) \\
& A=\frac{\ln C_{\mathrm{0}^{\prime}}-\ln C_{\mathrm{t}^{\prime}}}{t} \\
& I=F C
\end{aligned}
$$

where $F=$ filtration rate $\left(\mathrm{ml} \mathrm{h}^{-1}\right) ; C_{0}$ and $C_{\mathrm{t}}=$ initial and final cell concentrations (cells $\mathrm{ml}^{-1}$ ); $t=$ duration of experiment $(h) ; n=$ number of larvae in a given volume $V . A$ is the correction for any changes in the control group. $I=$ ingestion rate, and $C$ represents the arithmetic mean of cell concentration for the duration of the experiment (time $t$ ).

Measurements of oxygen uptake and heat dissipation by larvae under hypoxia/anoxia. The experimental protocol was similar to that used by Widdows et al. (1989). The rates of heat dissipation $\left(Q_{;} n J h^{-1}\right)$ and oxygen uptake $\left(\mathrm{NO}_{2} ;\right.$ pmol $\left.\mathrm{O}_{2} \mathrm{~h}^{-1}\right)$ of 4 larval stages $(106,155,180$ and $280 \mu \mathrm{m})$ under normoxia, hypoxia and anoxia were measured by open-flow simultaneous calorimetry and respirometry. Heat dissipation is a direct measure of the total metabolic energy expendi- ture, which can be partitioned into aerobic (respiration) and anaerobic components following the conversion of oxygen uptake into heat equivalents $\left(1 \mathrm{nmol} \mathrm{O}_{2} \mathrm{~h}^{-1}=\right.$ $-0.125 \mu W_{i}$ Gnaiger 1983). Larvae were placed in a 25 $\mathrm{ml}$ stainless perfusion chamber in a microcalorimeter (LKB 2277 Bioactivity Monitor). The number of larvae varied with body size (30000 larvae of $106 \mu \mathrm{m}, \mathrm{n}=3$; 25000 larvae of $155 \mu \mathrm{m}, \mathrm{n}=3 ; 24800$ larvae of $180 \mu \mathrm{m}$, $\mathrm{n}=1 ; 10000$ larvae of $280 \mu \mathrm{m}, \mathrm{n}=4)$. FSW was pumped from a reservoir through the perfusion chamber and then to a thermostated Radiometer oxygen sensor via $1 \mathrm{~mm}$ bore stainless steel tubing. A duplicate calorespirometric system containing only filtered seawater acted as the reference system monitoring both the baseline of the calorimeter and the oxygen level of the inflow seawater (for a detailed description of the calorespirometric system see Widdows 1987). Since earlier studies on Crassostrea virginica larvae found that the addition of algal cells to the FSW caused a significant drift of the heat flow in the 'reference system' over $24 \mathrm{~h}$, relative to heat flux from the larvae (Widdows et al. 1989), no attempt was made to feed the larvae during the whole experimental period of measurement. Flow rates of $20,25,25$ and $40 \mathrm{ml} \mathrm{h}^{-1}$ for 106 , 155, 180 and 280 um larvae were selected for the perfusion system, in order to achieve ca 5 to $10 \%$ removal of oxygen content from the inflowing seawater.

The calorimetric system reached a steady state within $3 \mathrm{~h}$ after larvae were placed in the calorimeter Rates of oxygen uptake and heat dissipation by larvae in fully air-saturated seawater (normoxia) were recorded continuously overnight (ca $10 \mathrm{~h}$ ). Then the $P_{\mathrm{O}_{2}}$ within the system was lowered in a stepwise manner from normoxia ( $20.5 \mathrm{kPa}$ ) to $7,4,2 \mathrm{kPa}$ over a period of 10 to $12 \mathrm{~h}$ by bubbling an appropriate mixture of oxygen and nitrogen into the reservoir. Each oxygen level was maintained for 3 to $4 \mathrm{~h}$ to establish steady-state recordings of the rates of heat flow and oxygen uptake. Below $2 \mathrm{kPa}$ the water was bubbled with $\mathrm{N}_{2}$ gas, reducing the $P_{\mathrm{O}_{2}}$ gradually to the anoxic state over $6 \mathrm{~h}$.

In addition, the metabolic rate of a group of $167 \mu \mathrm{m}$ larvae was measured during normoxia, anoxia and normoxic recovery. Heat dissipation and oxygen uptake by this group were first measured under normoxia for $10 \mathrm{~h}$, then the $P_{\mathrm{O}_{2}}$ in the reservoir was decreased rapidly to the anoxic state. Eight hours later the $P_{\mathrm{O}_{2}}$ within the calorespirometric chamber was allowed to rise rapidly to normoxic levels (reaching $63 \%$ of full air saturation in $6 \mathrm{~min}$ ) and the rates of heat flow/oxygen uptake were further monitored for ca $6 \mathrm{~h}$. As a result of rapid change in the rate of heat dissipation during the initial phase of recovery and the relatively slow response of the heat sensors, the apparent rate was converted to the instantaneous rate using the 
exponential delay correction (i.e. 12 min time constant for calorimetric system). No such correction was required for the oxygen sensors.

\section{RESULTS}

\section{Anoxia tolerance of different larval sizes}

The anoxia tolerance of mussel larvae was dependent on developmental stage, with the larger larvae being more tolerant than the smaller larvae (Fig. 1). Larval

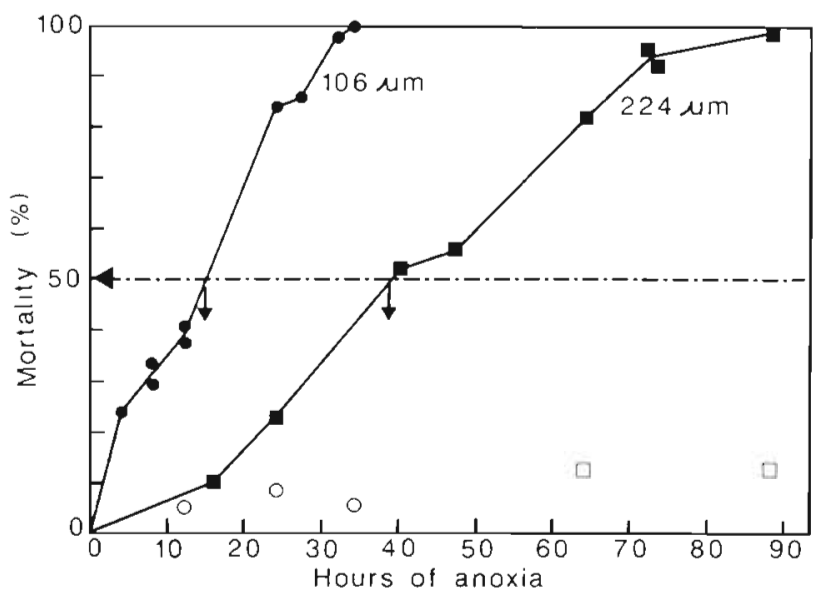

Fig. 1. Mytilus edulis. Relationship between cumulative mortality and duration of anoxia for larvae of $106 \mu \mathrm{m}$ and $224 \mu \mathrm{m}$ shell length

median mortality time (MMT; h) was estimated from the relationship between mortality rate and anoxia exposure period. Fifty percent mortality occurred at $14.7 \mathrm{~h}$ and $38.7 \mathrm{~h}$ for larvae of $106 \mu \mathrm{m}$ and $224 \mu \mathrm{m}$ respectively. Larvae in the normoxic controls (open symbols in Fig. 1) survived with very low mortality (4 to $13 \%$ ).

Within a few hours of exposure to anoxia most individuals would sink to the bottom of the syringes and remain inactive with shell valves closed. However, a few individuals were able to maintain their swimming activity for a few hours.

\section{Larval development and growth under hypoxic conditions}

\section{Embryonic development}

In 48 h hypoxia experiments (Fig. 2), there were no detectable effects of moderate hypoxia (5.91 and 3.16 $\mathrm{kPa}$ ) on the developmental process. At these $P_{\mathrm{O}_{2}}$ levels embryos developed into the prodissoconch larvae at
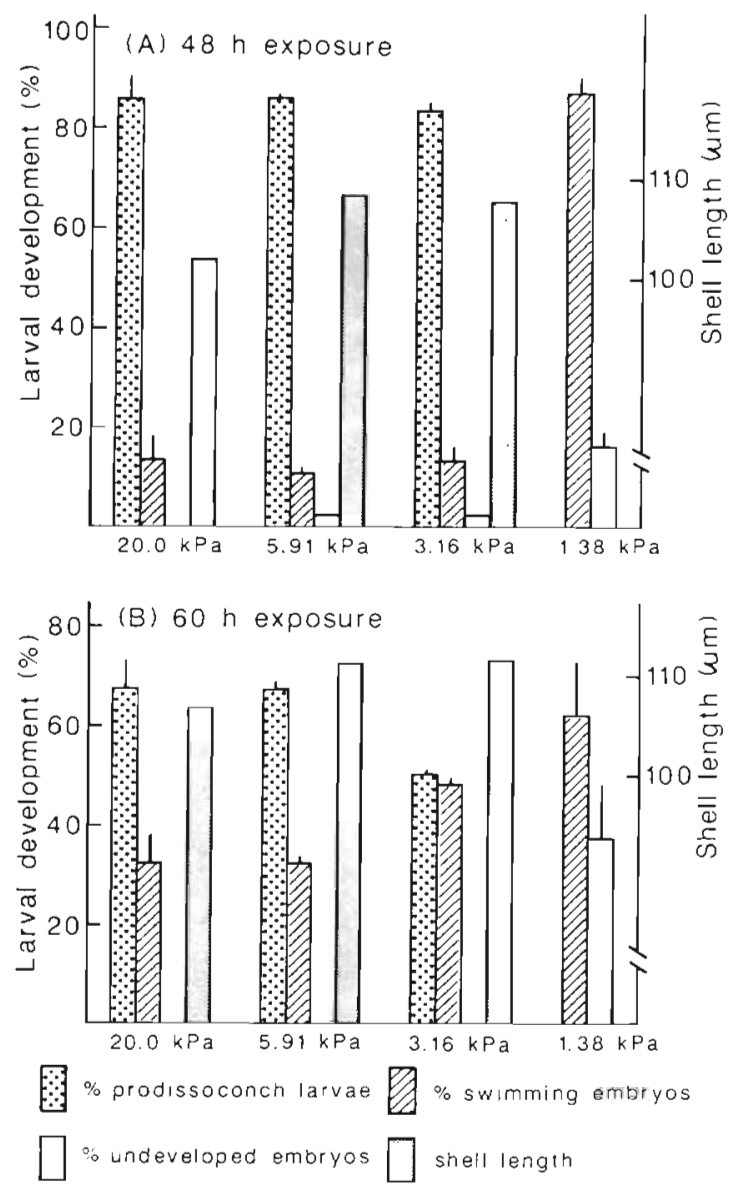

Fig. 2. Mytilus edulis. Effects of $P_{O},(\mathrm{kPa})$ on shell length and the proportion of undeveloped embryos, swimming embryos and prodissoconch larvae after (A) $48 \mathrm{~h}$ exposure; (B) $60 \mathrm{~h}$ exposure. (Mean \pm semi-range; $\mathrm{n}=2$ )

Table 1. Measurements of shell length $(\mu \mathrm{m})$ of prodissoconch larvae after 60 h exposure of embryos to different partial pressures of oxygen and during $9 \mathrm{~d}$ of recovery under normoxia (mean $\pm \mathrm{SE}$ )

\begin{tabular}{cccccc} 
Mean $P_{\mathrm{O}_{2}}$ during 60 h hypoxia & 0 & $\begin{array}{c}\text { Shell length after } 60 \mathrm{~h} \text { hypoxia } \\
6 \\
(\mathrm{kPa})\end{array}$ & $\begin{array}{c}3 \\
\text { (days of recovery) }\end{array}$ & $\begin{array}{c}\text { Growth rate }\left(\mu \mathrm{m} \mathrm{d}^{-1}\right) \\
\text { between } \\
\text { Days } 3 \text { and } 9\end{array}$ \\
\hline 20.0 & $106.7 \pm 0.52$ & $122.2 \pm 0.84$ & $143.3 \pm 1.38$ & $179.9 \pm 2.14$ & 9.62 \\
3.91 & $112.0 \pm 0.59$ & $124.1 \pm 0.75$ & $144.7 \pm 1.71$ & $179.6 \pm 1.64$ & $9.25(\mathrm{p}>0.15 ; \mathrm{NS})$ \\
1.16 & $112.8 \pm 0.61$ & $123.8 \pm 0.91$ & $145.1 \pm 1.51$ & $178.1 \pm 1.43$ & $9.05(\mathrm{p}>0.15 ; \mathrm{NS})$ \\
& Embryos & $118.4 \pm 1.24$ & $138.9 \pm 3.08$ & $172.2 \pm 1.70$ & $8.97(\mathrm{p}>0.15 ; \mathrm{NS})$ \\
\hline
\end{tabular}




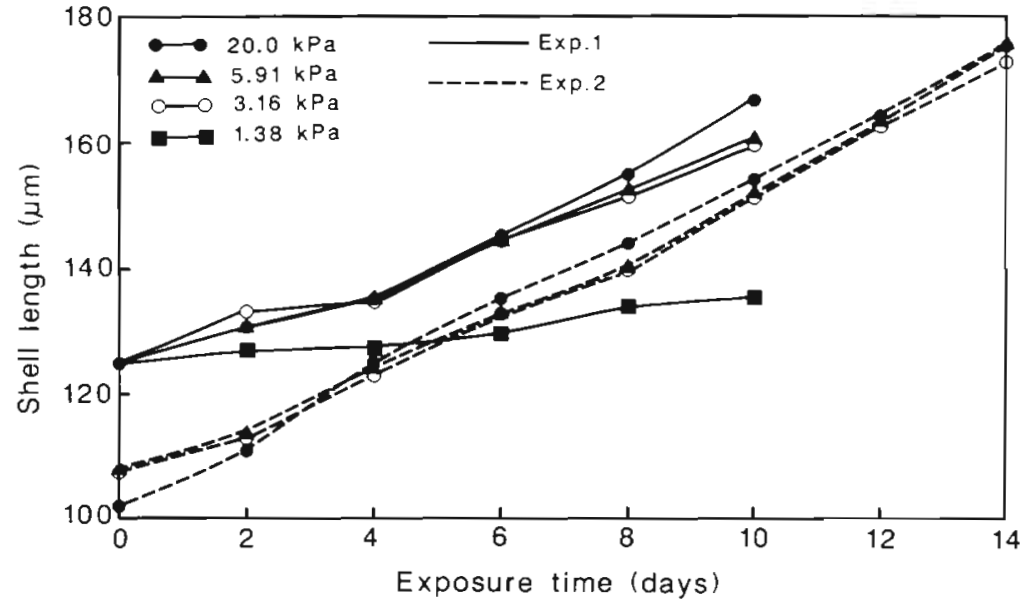

rates comparable to those under normoxic conditions. In the $60 \mathrm{~h}$ hypoxia experiment, all fertilized eggs developed into the pelagic larval phase, but the proportion of larvae reaching the prodissoconch stage was lower at $3.16 \mathrm{kPa}$ than at $5.91 \mathrm{kPa}$ and under normoxia. In contrast, under the most extreme hypoxic condition $(1.38 \mathrm{kPa})$, fertilised eggs developed only to the gastrula stage, with no further development into prodissoconch larvae. Continuous exposure of these gastrula embryos under the same $P_{\mathrm{O}_{2}}$ level confirmed that they eventually died after $4 \mathrm{~d}$. The shell lengths of these hypoxic prodissoconch larvae were significantly greater than the normoxic control larvae $(48 \mathrm{~h}$ experiment, $\mathrm{p}<0.05 ; 60 \mathrm{~h}$ experiment, $\mathrm{p}<0.005$; ANOVA). The cause of this result is unknown.

Growth rates of recovered prodissoconch larvae, following $60 \mathrm{~h}$ hypoxic exposure during their embryonic development, were not significantly different from the control larvae (Table 1). Nevertheless, only ca $3 \%$ of the gastrula embryos that developed under $1.38 \mathrm{kPa}$ recovered under normoxia and developed further into prodissoconch larvae. These larvae were slightly smaller than the 'normoxic' and other 'hypoxicrecovery' larvae, due in part to a delay in development (Table 1). The majority of gastrula embryos developed into a larval stage without a shell, but with a perfect velum structure. These abnormal 'larvae' had a mean size of $72.0 \mu \mathrm{m}$ and in many cases had a ' $D$ ' shape. They survived under normoxic conditions for at least $19 \mathrm{~d}$, during which time there was no shell formation or growth. However, evidence based on the presence of food particles revolving within the stomach suggested that they were able to capture the particles from the surrounding water using the velum. Consequently, we speculate that extreme hypoxia $(<2 \mathrm{kPa})$ interferes with normal development from trochophore to the prodissoconch stage, particularly the formation of the shell gland and/or shell secretion.
Fig. 3. Mytilus edulis. Growth in shell length by early prodissoconch larvae under normoxia and various levels of hypoxia. Exp. 1 (solid lines) was initiated with larvae of $124 \mu \mathrm{m}$ on Day 0; Exp. 2 (dotted lines) was initiated with embryos. Thus shell lengths on Day 0 were the sizes of prodissoconch larvae developed from embryos at each condition. (Mean $\left.n_{i}=2\right)$

\section{Larval growth}

Early larval stages maintained growth under hypoxia until the $P_{\mathrm{O}_{2}}$ decreased to $1.38 \mathrm{kPa}$ (Fig. 3). One experiment initiated from the fertilised eggs showed that there was a similar rate of shell growth under normoxia and moderate levels of hypoxia during the whole exposure period (14 d). In another experiment, which began with larvae of $124 \mu \mathrm{m}$ shell length, the growth rates of normoxic and $5.91 \mathrm{kPa}$ and $3.16 \mathrm{kPa}$ groups were comparable during the first $6 \mathrm{~d}$. However, when the larvae had reached a size of 150 to $160 \mu \mathrm{m}$ the growth

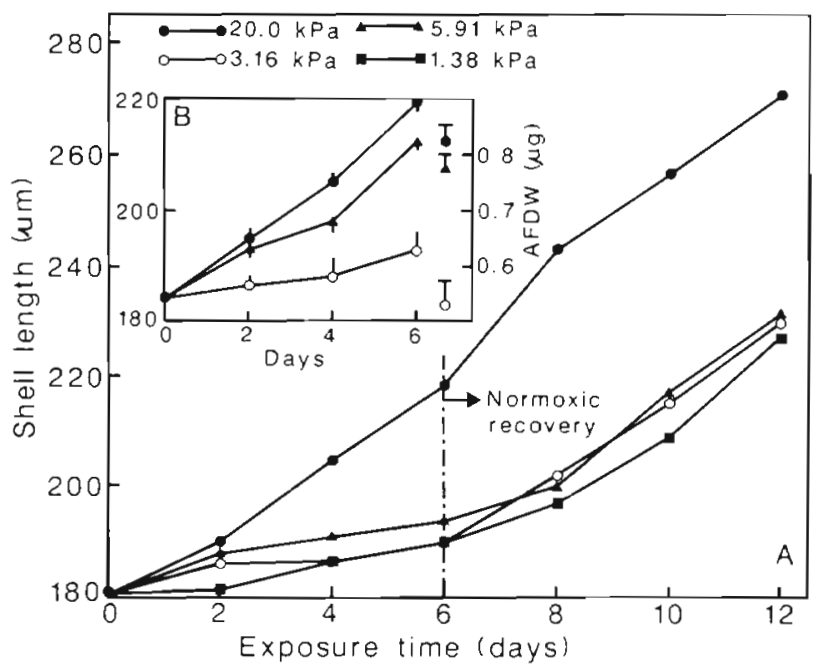

Fig. 4. Mytilus edulis. (A) Growth of veliconch larvae (shell length $180 \mu \mathrm{m}$ ) held at various $P_{\mathrm{O}}$, levels (flow rate $53 \mathrm{ml} \mathrm{h}^{-1}$; chamber volume $500 \mathrm{mll}$ ). On Day 6 , larvae were recovered under normoxic conditions and their shell lengths measured every 2 d. (B) Inset: Experiment undertaken in a smaller volume of water $(100 \mathrm{ml})$ and at a higher flow rate $\left(70 \mathrm{ml} \mathrm{h}^{-1}\right)$. AFDW represents ash-free dry weight of larvae following $6 \mathrm{~d}$ hypoxic exposure (Mean $\pm \mathrm{SE}, \mathrm{n}=8$ ). For full explanation, see text 
rates of controls and the 2 hypoxic groups between 6 and 10 d were significantly different $(\mathrm{p}<0.05$, ANOVA\}.

Increases in shell length of veliconch larvae $(180 \mu \mathrm{m}$ initial shell length) during $6 \mathrm{~d}$ exposure to hypoxia are presented in Fig. 4. Larval growth rates were significantly reduced $(\mathrm{p}<0.05)$ at the lower $P_{\mathrm{O}_{2}}$ levels $(3.16$ and $1.39 \mathrm{kPa}$ ), but the degree of suppression at 5.91 $\mathrm{kPa}$ varied with experiments. This was probably dependent on turnover time within the experimental chamber and thus the oxygen delivered per unit time. In one experiment, where the turnover time was shorter (flow rate of $70 \mathrm{ml} \mathrm{h}^{-1}$ through $100 \mathrm{ml}$ chamber) the growth rate was between the 'normoxic' controls and the $3.16 \mathrm{kPa}$ condition (Fig. $4 \mathrm{~B}$ ); in the other, where the turnover time was longer (flow rate of $53 \mathrm{ml} \mathrm{h}^{-1}$ through $500 \mathrm{ml}$ chamber), growth rates at $5.91 \mathrm{kPa}$ were not significantly different from those at 3.16 and $1.38 \mathrm{kPa}$ (Fig. 4A). This variation in growth rate at ca 5 to $6 \mathrm{kPa}$ may be referred to as the critical $P_{\mathrm{O}_{2}}$ level for larval growth. The ash-free dry weight of larvae after $6 \mathrm{~d}$ hypoxic exposure is also presented in Fig. 4B. These values did not deviate significantly from the expected values calculated from the shell length according to Eq. (2), suggesting that the inhibition of growth due to hypoxic stress can be adequately quantified by shell length measurements.

Recovery under normoxia after $6 \mathrm{~d}$ hypoxic exposure showed no evidence of 'catch-up' growth, but a growth rate comparable to the control larvae (no significant difference, $\mathrm{p}>0.1$ ) was reached after $2 \mathrm{~d}$ of recovery. Comparison of daily shell length increments among these groups indicated that a full recovery of growth rate did not occur during the first $2 \mathrm{~d}$ (between Days 6 and 8 , control larvae having a growth rate of $12.7 \mu \mathrm{m}$ $\mathrm{d}^{-1}$ compared to the 'hypoxic' larvae with growth rates from 3 to $6.5 \mu \mathrm{m} \mathrm{d}^{-1}$ ).

Responses of $240 \mu \mathrm{m}$ larvae highlighted a contrasting effect of hypoxia on growth rate and development of 'eye-spots'; an important stage in larval differentiation and development (Fig. 5A, B). Even though growth was considerably reduced at all hypoxic levels, larval development shown by the formation of 'eye-spots' still proceeded, albeit with a delay that lasted for several days depending upon the availability of oxygen. For example, at 5.91 and $3.16 \mathrm{kPa}$, development of 'eyes' was delayed by 1 and $2 \mathrm{~d}$; and by more than $6 \mathrm{~d}$ at 1.38 $\mathrm{kPa}$. Furthermore, on Day 8 , before the larvae were allowed to settle on byssal threads, more than $90 \%$ of the larvae in 5.91 and $3.16 \mathrm{kPa}$ had developed into the 'eyed' stage and at $1.38 \mathrm{kPa}$, the proportion had reached only $40 \%$. The shell length at which about $50 \%$ of larvae entered the 'eyed stage' (calculated from Fig. 5A, B) was 255.3, 247.5, 246.2, 245.9 $\mu \mathrm{m}$ for the normoxia $(20 \mathrm{kPa}), 5.91 \mathrm{kPa}, 3.16 \mathrm{kPa}$ and $1.38 \mathrm{kPa}$

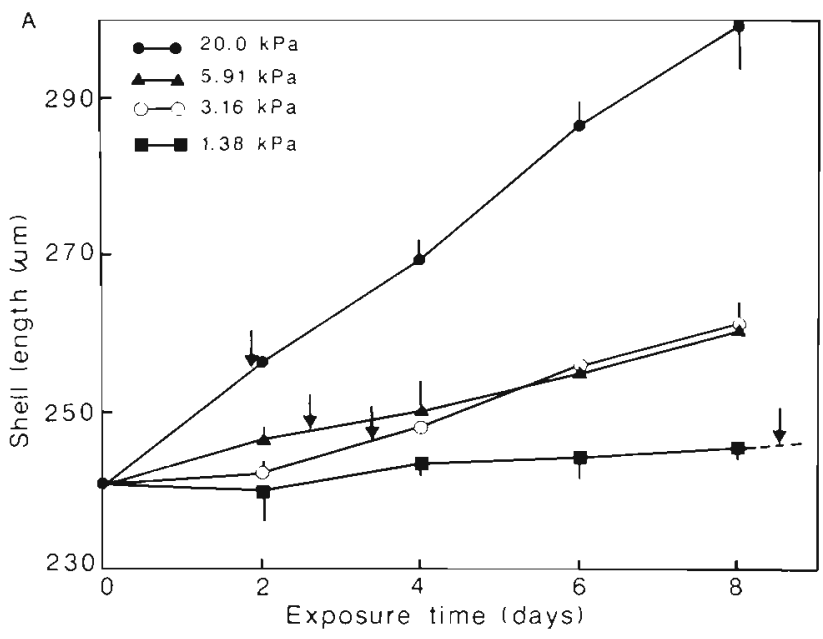

B

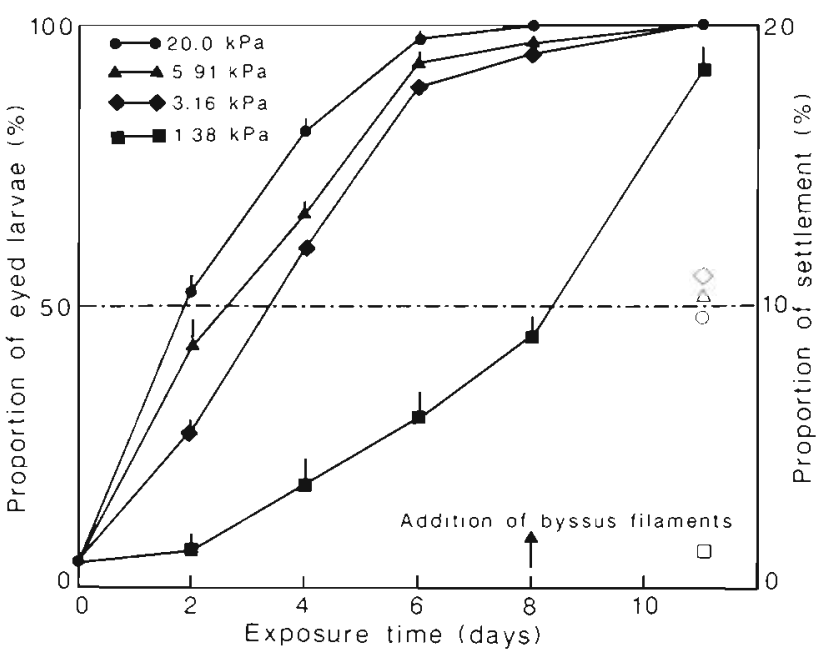

Fig. 5. Mytilus edulis. (A) Growth of veliconch larvae (initial shell length, $240 \mu \mathrm{m}$ ) at various $P_{O_{2}}$ levels in relation to duration of exposure. Arrows indicate shell lengths at which $50 \%$ of larvae developed 'eye spots' (mean \pm semi-range); (B) percentage of larvae with 'eye spots' in relation to duration of hypoxic exposure. On Day 8 , byssus filaments of adult mussels were provided, allowing competent larvae to settle. The proportions of 'eye' larvae attached on Day 11 are shown on the right (open symbols). (Mean \pm semi-range; $n=2$ )

groups respectively. Consequently, veliconch mussel larvae exposed to hypoxia developed their 'eye-spots' at a smaller size (246 to $248 \mu \mathrm{m}$ ) compared to those grown under normoxia $(255 \mu \mathrm{m})$.

On Day 8, all larvae were provided with byssus filaments and agitation to induce settlement. Results showed that the proportion of larvae settling and attaching to the filaments was similar at least down to a $P_{\mathrm{O}_{2}}$ level of $3.16 \mathrm{kPa}$ (Fig. 5B). In another experiment, pediveliger larvae reared under normoxic conditions were held in small chambers $(100 \mathrm{ml})$ without agitation but with a high rate of water exchange (flow rate ca 
$100 \mathrm{ml} \mathrm{h}^{-1}$ ) and exposed to various levels of hypoxia for $2 \mathrm{~d}$. The results confirmed the findings in that moderate hypoxia had little effect on settlement. Approximately $12 \%$ of larvae settled onto the byssus filaments of adult mussels under normoxia, $5.91 \mathrm{kPa}$ and $3.16 \mathrm{kPa}$, whereas only $1 \%$ settled at $1.39 \mathrm{kPa}$.

\section{Behavioural observation}

Although behavioural responses to hypoxia were not quantified in this study, swimming behaviour and distribution of larvae in the water column were observed during the growth period examined. Larvae maintained under hypoxia had an identical swimming behaviour to those under normoxia, namely, the vertically orientated straight movement or cylindrical helical movement (Cragg 1980). However, there was a notable difference in their distribution in the water

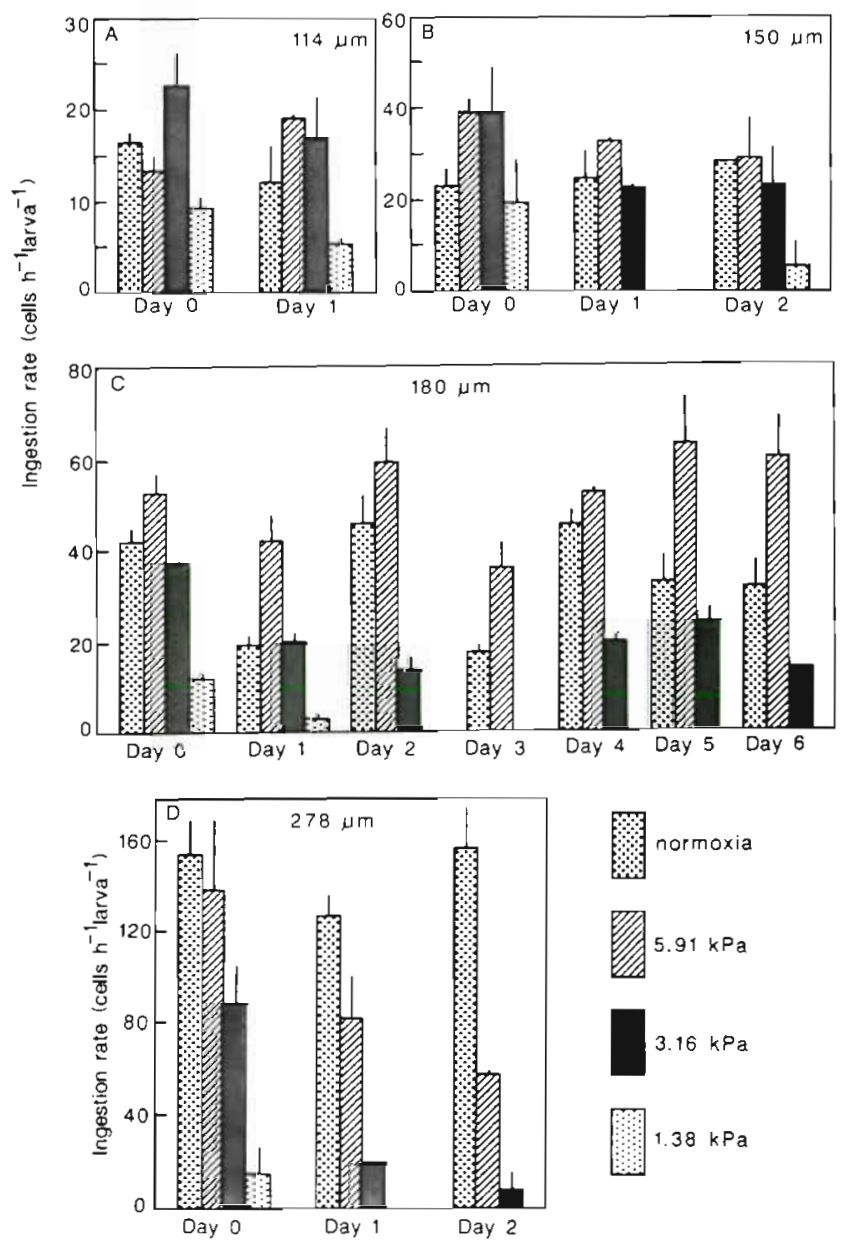

Fig. 6. Mytilus edulis. Ingestion rates at various larval sizes under normoxic and hypoxic conditions in relation to duration of exposure. Acute exposure of larvae is defined as Day 0 . (a) $114 \mu \mathrm{m}$ shell length; (b) $150 \mu \mathrm{m}_{\text {; }}$ (c) $180 \mu \mathrm{m}_{\text {; }}$ (d) $278 \mu \mathrm{m}$. (Mean \pm semi-range $; n=2$ ) column. In contrast to larvae under normoxia, those under hypoxic conditions were distributed primarily near the upper layers of the water column. In general, such a distribution was recorded several hours ( 2 to $3 \mathrm{~h}$ ) after the larvae were introduced into the hypoxic seawater and it was maintained over the whole exposure period.

\section{Effect of hypoxia on ingestion rates}

Two size classes of early larvae (114 and $150 \mu \mathrm{m}$ ) were able to sustain or even enhance their feeding activity at $P_{\mathrm{O}_{2}}$ levels ranging from normoxia down to $3.16 \mathrm{kPa}$ (Fig. 6A, B). The ingestion rates (acute response, Day 0) of the $150 \mu \mathrm{m}$ larvae at both 5.91 and $3.16 \mathrm{kPa}$ were nearly $71 \%$ higher than the larvae under normoxia, but a similar dramatic increase in feeding activity of $114 \mu \mathrm{m}$ larvae was only at $3.16 \mathrm{kPa}$. However, the feeding rates were then maintained similar to the control larvae after 1 or $2 \mathrm{~d}$ exposure to these levels of hypoxia. At $1.38 \mathrm{kPa}$, the ingestion rates were depressed and depression became more evident with increasing exposure period (Fig. 6A, B).

The feeding rates of veliconch larvae $(180 \mu \mathrm{m})$ under normoxia and hypoxia were measured daily for up to $6 \mathrm{~d}$ (Fig. 6C). Results suggested a marked contrast to the earlier larval stages: ingestion rates under moderate hypoxia $(5.91 \mathrm{kPa})$ were consistently higher than the control larvae throughout $6 \mathrm{~d}$ of measurements, in spite of daily variation in feeding activity by larvae under normoxia. At $3.16 \mathrm{kPa}$, larval feeding activity was maintained on Days 0 and 1, but declined thereafter to an ingestion rate $55 \%$ of the controls at the end of the experiment. The suppression of feeding activity of larvae at $1.38 \mathrm{kPa}$ was very marked and feeding activity was not detectable after $2 \mathrm{~d}$ exposure.

The ingestion rate of the pediveliger larvae showed a more $P_{\mathrm{O}_{2}}$-dependent response (Fig. 6D). Larvae reduced their feeding activity in response to a decrease in oxygen availability and an increase in duration of exposure. For example, under normoxia the ingestion

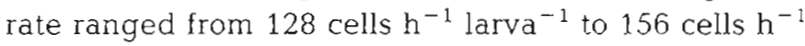
larva ${ }^{-1}$ and this was reduced by 60 and $90 \%$ after $2 \mathrm{~d}$ exposure to 5.91 and $3.16 \mathrm{kPa}$, respectively. Again at $1.38 \mathrm{kPa}$ there was no evidence of feeding by pediveliger larvae on Days 1 and 2, and the guts were found to be empty by the end of exposure period ( $2 \mathrm{~d}$ ).

\section{Effects of hypoxia and anoxia on rates of oxygen uptake and heat dissipation}

The rates of oxygen uptake and heat dissipation by 4 different larval stages $(106,155,180,280 \mu \mathrm{m})$ in 

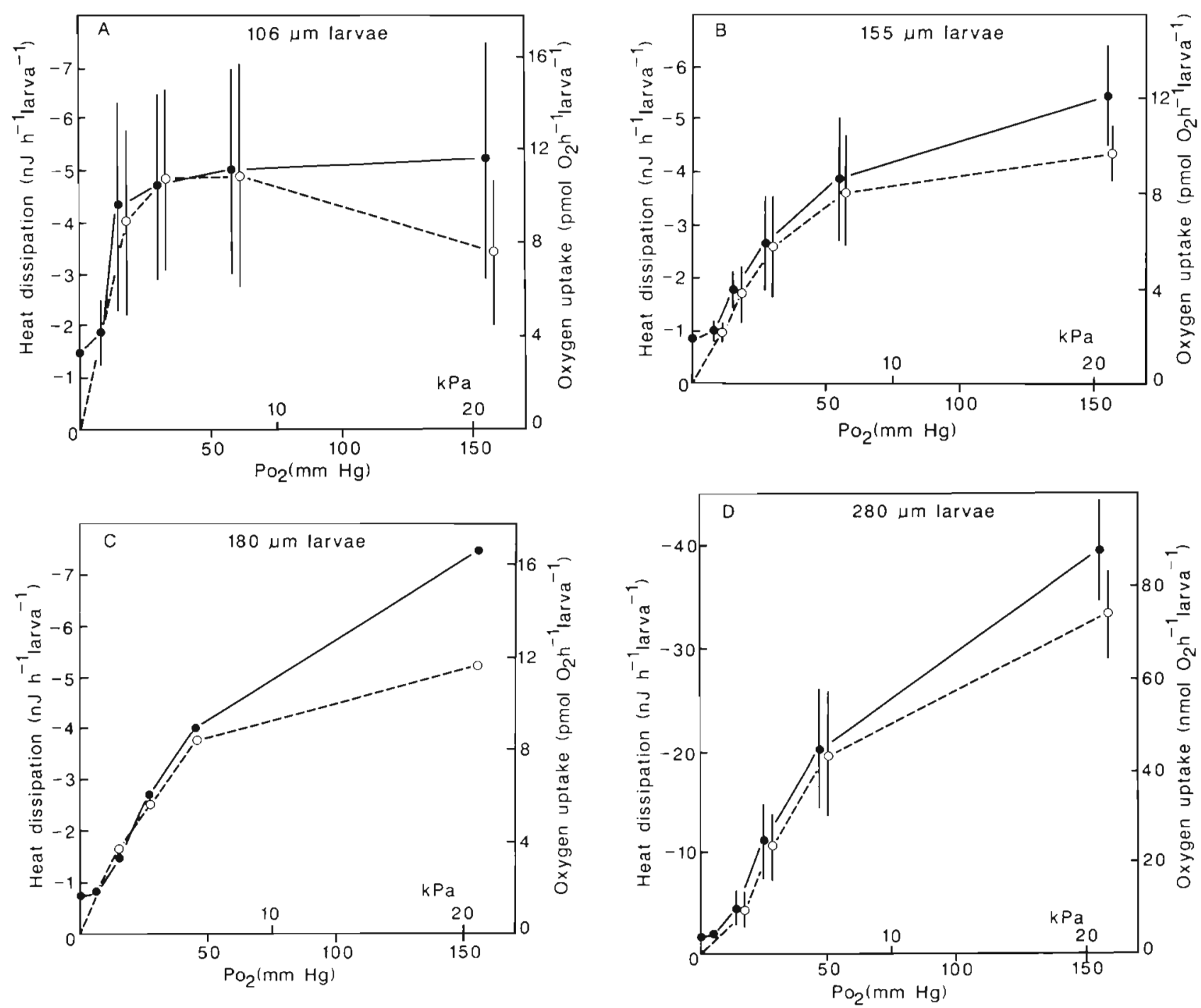

Fig. 7. Mytilus edulis. Rates of oxygen uptake (pmol $\mathrm{O}_{2} \mathrm{~h}^{-1}$ larva ${ }^{-1}$; 0 ) and heat dissipation $\left(\mathrm{nJ} \mathrm{h}^{-1}\right.$ larva ${ }^{-1}$; $\bullet$ ) by different larval stages in relation to $P_{\mathrm{O}_{2}}$. (A) $106 \mu \mathrm{m}$ (means \pm semi-range, $\mathrm{n}=3$ ); $(\mathrm{B}) 155 \mu \mathrm{m}$ (means \pm semi-range, $\mathrm{n}=3$ ); $(\mathrm{C}) 180 \mu \mathrm{m}(\mathrm{n}=1)$; (D) $280 \mu \mathrm{m}$ (means \pm semi-range, $\mathrm{n}=4$ ); Rates of heat dissipation and oxygen uptake are plotted on corresponding scales using an oxycaloric equivalent of $-450 \mathrm{~kJ} \mathrm{~mol}^{-1} \mathrm{O}_{2}$

response to a stepwise decrease in the partial pressure of oxygen are illustrated in Fig. 7. All larval sizes reduced their metabolic rates under hypoxia and anoxia, although the character of the response varied with developmental stage/larval size. The evaluated critical partial oxygen pressure $\left(P_{c}\right.$ Herreid 1980$)$ and the calculated $P_{\mathrm{O}_{2}}$ at which metabolic rate was $50 \%$ of the normoxic rate for each larval size are listed in Table 2.

Early prodissoconch larvae (106 $\mu \mathrm{m}_{i}$ Fig. 7A) were able to maintain their rates of oxygen uptake and heat dissipation independent of partial pressure of oxygen down to $2 \mathrm{kPa}$, whilst early veliconcha $(155 \mu \mathrm{m})$ could only maintain their rates down to $7.3 \mathrm{kPa}$. With increas- ing larval size $(180,280 \mu \mathrm{m})$ the rates of heat dissipation and oxygen uptake became more $P_{\mathrm{O}_{2}}$ dependent. The $P_{\mathrm{O}_{2}}$ at which heat dissipation rates declined to $50 \%$ of the normoxic rates were $1.3,3.7,5.6$ and $6.1 \mathrm{kPa}$ for $106,155,180$ and $280 \mu \mathrm{m}$ larvae respectively.

The calculated experimental oxycaloric equivalents of these larval sizes under normoxia and hypoxia are presented in Table 3 . When the experimentally derived oxycaloric equivalents are significantly higher than the generalised oxycaloric equivalents $(-440$ to $-480 \mathrm{~kJ}$ $\mathrm{mol}^{-1} \mathrm{O}_{2}$; Gnaiger 1983), a significant anaerobic contribution to the total energy metabolism is indicated. There was evidence of an anaerobic component in the total energy expenditure of larvae under normoxic con- 
Table 2. Descriptors of the effects of oxygen partial pressure $\left(P_{\mathrm{O}_{2}}\right)$ on the metabolic rate of 4 sizes of Mytilus edulis larvae. $\mathrm{Q}$ : rate of heat dissipation ( $\mathrm{n} \cdot \mathrm{J} \mathrm{h}^{-1}$ larva ${ }^{1}$ ); $\mathrm{N}_{\mathrm{O}_{2}}$ : rate of oxygen uptake (pmol $\mathrm{O}_{2} \mathrm{~h}^{-1}$ larva ${ }^{-1}$ )

\begin{tabular}{|c|c|c|c|c|}
\hline \multirow[b]{2}{*}{ Descriptor } & \multicolumn{4}{|c|}{ Shell length $(\mu \mathrm{m})$} \\
\hline & 106 & 155 & 180 & 280 \\
\hline$P_{\mathrm{c}}(\mathrm{kPa})^{\mathrm{a}}$ & 2.0 & 7.3 & $>7.3$ & $>7.3$ \\
\hline$P_{\mathrm{O}_{2}}(\mathrm{kPa})$ at $0.5 Q_{\text {normoxia }}{ }^{\mathrm{b}}$ & 1.33 & 3.7 & 5.6 & 6.1 \\
\hline$P_{\mathrm{O}_{2}}(\mathrm{kPa})$ at $0.5 N_{\mathrm{O}_{2}(\text { normoxia })}{ }^{\mathrm{C}}$ & 1.06 & 3.2 & 3.7 & 5.7 \\
\hline$Q_{\text {anoxia }} d / Q_{\text {normoxia }}$ & 0.29 & 0.13 & 0.064 & 0.058 \\
\hline \multicolumn{5}{|c|}{$\begin{array}{l}{ }^{a} P_{\mathrm{c}} \text { critical oxygen partial pressure }\left(P_{\mathrm{O}_{2}} \text { below which } Q\right. \\
\text { and } \mathrm{N}_{\mathrm{O}_{2}} \text { become oxygen dependent) } \\
\text { b }{ }^{\mathrm{O}_{2}} \text { at } 0.5 Q_{\text {normoxia }}: P_{\mathrm{O}_{1}} \text { that reduces rate of heat dissipa- } \\
\text { tion to } 50 \% \text { of normoxic rate } \\
{ }^{c} P_{\mathrm{O}_{2}} \text { at } 0.5 \mathrm{~N}_{\mathrm{O}_{2} \text { (normoxiar: }} P_{\mathrm{O}_{2}} \text { that reduces rate of oxygen } \\
\text { consumption to } 50 \% \text { of normoxic rate } \\
\text { d } Q_{\text {anoxia: }} \text { rate of heat dissipation during initial } 3 \mathrm{~h} \text { of anoxia }\end{array}$} \\
\hline
\end{tabular}

ditions, since the measured oxycaloric equivalents of all larval stages were higher than the theoretical oxycaloric equivalent. This anaerobic component may be due to brief periods of valve closure and quiescence shown by a proportion of larvae under normoxia, whereas under moderate levels of hypoxia they become more active (swimming and feeding) and this is reflected in a fully aerobic metabolism.

The rate of anoxic heat dissipation by larvae $\left(Q_{\text {anoxia }}\right)$ was calculated as a proportion of the normoxic rate of heat dissipation (i.e. $Q_{\text {anoxia }} / Q_{\text {normoxia; }}$ Table 2). Early larval stages (106 and $154 \mu \mathrm{m}$ ) had a relatively high rate of anoxic energy metabolism, 29 and $13 \%$ of the normoxic rate respectively. In contrast, 180 and $280 \mu \mathrm{m}$ larvae had a lower anoxic rate of heat dissipation, 6.4 and $5.8 \%$ of the normoxic rate respectively.

\section{Recovery from anoxia}

In one experiment, the rates of heat dissipation and oxygen uptake by veliconch larvae $(167.0 \mu \mathrm{m})$ were recorded during normoxic recovery following $8 \mathrm{~h}$ of anoxic exposure. Within the first hour of recovery there was a significant overshoot of rates of both heat dissipation and oxygen uptake (ca 25\% and ca 300\% respectively; Fig. 8). These rates returned to a relatively steady state after $3 \mathrm{~h}$ recovery but oxygen uptake continued to decrease a little further. The experimental oxycaloric equivalent after $45 \mathrm{~min}$ of recovery was $-219 \mathrm{~kJ} \mathrm{~mol}^{-1} \mathrm{O}_{2}$ and after $3 \mathrm{~h}$ had reached $-457 \mathrm{~kJ}$ $\mathrm{mol}^{-1} \mathrm{O}_{2}$. Beyond this recovery period, the experimental oxycaloric equivalent increased due to a decline in the rate of oxygen uptake, presumably as a proportion of larvae became inactive and closed their valves.

\section{DISCUSSION}

\section{Larval response to anoxia}

In a recent investigation of the anoxia tolerance of Crassostrea virginica larvae, Widdows et al. (1989) found that the larger/older larvae were more resistant to anoxia than the smaller/younger larvae. The median mortality time (MMT) under anoxic conditions increased from $11 \mathrm{~h}$ in $82 \mu \mathrm{m}$ larvae to as long as $51 \mathrm{~h}$ in pediveliger larvae $(312 \mu \mathrm{m})$. Larvae of Mytilus edulis (reared at $15^{\circ} \mathrm{C}$ and 31 ppt salinity) appear to have a comparable MMT values to those of $C$. virginica larvae (reared at $22{ }^{\circ} \mathrm{C}$ and $12 \mathrm{ppt}$ salinity) for each corresponding developmental stage; i.e. the MMT increased from $15 \mathrm{~h}$ for early prodissoconch larvae $(106 \mu \mathrm{m})$ to $39 \mathrm{~h}$ for 224 um larvae.

The differences in anoxia tolerance of the various larval sizes/stages are reflected in the metabolic responses of the larvae. Widdows et al. (1989) showed that there was a linear relationship between the ratio of anoxic heat dissipation to normoxic heat dissipation $\left(Q_{\text {anoxia }} / Q_{\text {normoxia }}\right.$ ) and the reciprocal of anoxia tolerance $(1 / \mathrm{MMT})$ at each larval stage of $C$. virginica. The present study confirms this relationship with a relatively higher $Q_{\text {anoxia }} / Q_{\text {normoxua }}$ (i.e. $29 \%$ ) during the early larval stages $(106 \mu \mathrm{m})$, compared to ca $6 \%$ for the later veliconch and pediveliger larval stages. The lower

Table 3. Mytilus edulis. Experimental oxycaloric equivalents $\left(\mathrm{kJ} \mathrm{mol}^{-1} \mathrm{O}_{2}\right)$ derived by simultaneous direct calorimetric and respirometric measurements of Iarvae under normoxia and hypoxia

\begin{tabular}{|ccccc|}
\hline$P_{\mathrm{O},}(\mathrm{kPa})$ & \multicolumn{2}{c}{ Larval size $(\mu \mathrm{m})$} & 180 & 280 \\
\hline 20.5 & 106 & 155 & -634.9 & $-535.3 \pm 10.4$ \\
6.5 & $-676.4 \pm 51.4$ & $-557.2 \pm 30.2$ & -479.5 & $-464.2 \pm 16.4$ \\
3.5 & $-481.4 \pm 34.9$ & $-484.3 \pm 13.7$ & -457.1 & $-468.8 \pm 18.1$ \\
2 & $-436.5 \pm 7.2$ & $-457.7 \pm 15.4$ & -444.1 & $-491.1 \pm 36.7$ \\
0.9 & $-477.3 \pm 12.8$ & $-474.2 \pm 43.6$ & -489.1 & - \\
0 & - & $-459.0 \pm 22.1$ & $\infty$ & $\infty$ \\
\hline
\end{tabular}




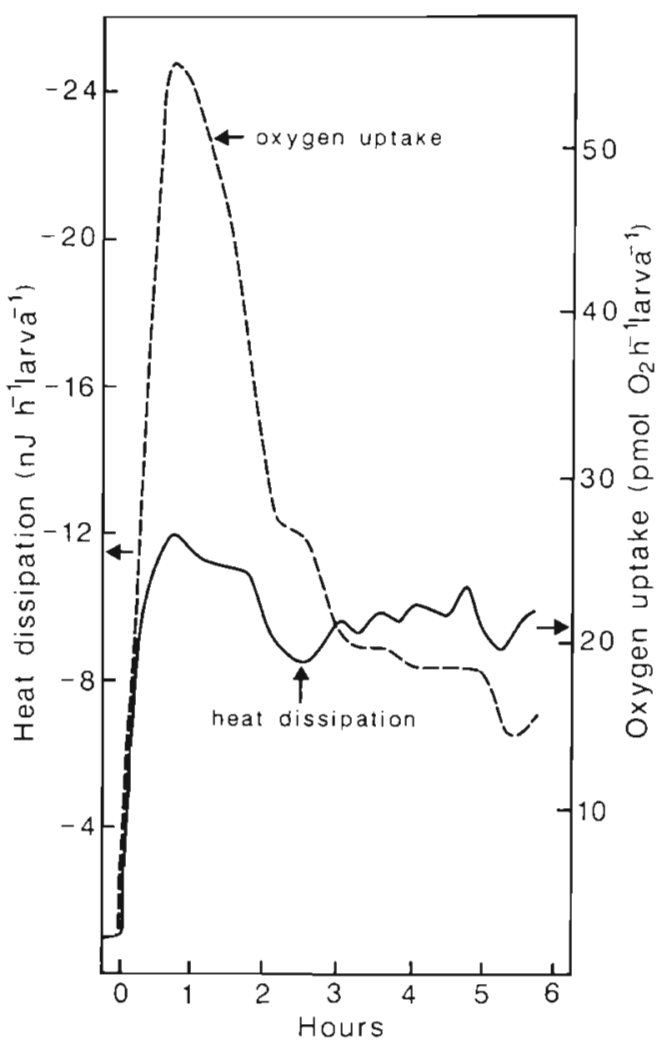

Fig. 8. Mytilus edulis. Continuous simultaneous measurement of rates of heat dissipation and oxygen uptake by $167 \mu \mathrm{m}$ larvae during recovery (under normoxia) after ca $8 \mathrm{~h}$ of anoxia. Both rates are plotted on corresponding scales using an oxycaloric equivalent of $-450 \mathrm{~kJ} \mathrm{~mol}{ }^{-1} \mathrm{O}_{2}$. Arrows on $\mathrm{Y}$-axes indicate pre-anoxic steady state rate of heat dissipation and oxygen uptake

anoxia tolerance of early larvae is probably the result of the high energetic costs associated with the maintenance of a relatively high rate of anaerobic metabolism and the small energy reserves in the early developmental stages (Gabbott 1976). However, results from the later larval stages do suggest a comparable degree of metabolic suppression to that typically found in the adult mussels under anoxia (i.e. $4 \%$; Widdows 1987). Consequently, there appears to be a shift in the level of anoxibiosis during larval development of Mytilus edulis, from a high ATP turnover rate in the early prodissoconcha and veliconcha stages, to a low ATP turnover rate and thus a comparatively lower rate of substrate utilisation in the later larval stages. Although various aspects of the anaerobic metabolic pathways utilised by adult mussels have been intensively studied over the past decade (for review see de Zwaan 1983, de Zwaan \& Putzer 1985), the pathways utilised by the early larval stages during anoxia have not been investigated. In contrast to the adult mussel, which stores glycogen as its primary energy reserve, the early larval stage relies heavily on lipid reserves which cannot be utilised under anoxia. Clearly, further studies are required to interpret these differences in anoxic energy metabolism displayed by various larval stages of mussels and other bivalves.

\section{Behavioural responses to hypoxia}

Widdows et al. (1989) and Mann \& Rainer (unpubl.) have demonstrated that larvae of Crassostrea virginica maintain their swimming activity at least during the first hours of hypoxic exposure, although different stages might differ in their response to prolonged hypoxic exposure. In terms of swimming rate there was no significant reduction as the ambient oxygen concentration declined, except at the lowest $P_{\mathrm{O}_{2}}$ examined ( $10 \%$ of oxygen saturation; Mann \& Rainer unpubl.). In the present study mussel larvae were able to maintain their locomotory activity during whole hypoxic exposure periods lasting several days. Only under the most hypoxic condition $(1.38 \mathrm{kPa}$ ) did the early prodissoconch larvae show retarded swimming and feeding activity, due primarily to abnormal development of the velum structure at this level of hypoxia. Most prodissoconch larvae at this level of hypoxia had a narrower and more extended velum compared to larvae at other hypoxic and normoxic conditions. We showed that a major behavioural response of mussel larvae to hypoxia included a significant upward swimming movement, which is likely to be of ecological significance for larvae to escape an hypoxic environment, i.e. to reach a higher level in the water column, where the oxygen concentration is generally greater.

Eyster \& Pechenik (1987) were able to enhance settlement of the pediveliger larvae of mussels onto adult byssus filaments (i.e. 31 to $100 \%$ ) by agitating the water. In our study, however, the proportion of larvae settling and attaching under normoxia was only ca $10 \%$, in spite of identical experimental conditions and a shaking period of $3 \mathrm{~d}$. Such a lower rate of settlement may be the result of less efficient water agitation in a sealed experimental chamber, as well as the relative age/competence of the pediveliger larvae. Nevertheless, our results suggest that oxygen concentration is not an important environmental stimulus for mussel larvae to select suitable sites for settlement. The proportion of pediveliger larvae settling onto the adult byssus threads was comparable to the normoxic rate at least until the $P_{\mathrm{O}_{2}}$ was decreased to $1.38 \mathrm{kPa}$. Rather, water current may be an overriding stimulus, presumably because in the field a high current speed generally will provide both suspended particulates and oxygen to meet the mussel's requirements. 


\section{Effect of hypoxia on physiological responses of larvae}

Morrison (1971) has shown that Mercenaria mercenaria embryos develop normally at oxygen concentrations above $0.5 \mathrm{mg} \mathrm{l}^{-1}$ (or $1.44 \mathrm{kPa}$ at 28 to $30 \mathrm{ppt}$ salinity and $25^{\circ} \mathrm{C}$ ), whereas the growth rates of early veliger larvae are reduced at oxygen concentrations of $2.4 \mathrm{mg} \mathrm{l}^{-1}$ (or $7.03 \mathrm{kPa}$ ). Recent studies by Huntington \& Miller (1989) demonstrate a less sensitive response by the veliger larvae of this bivalve, i.e. no significant decrease in larval growth rate at oxygen concentrations down to $1 \mathrm{mg} \mathrm{l}^{-1}(3 \mathrm{kPa})$. They attribute this difference to geographic variation and/or different larval densities used in both studies [e.g. 15000 larvae $1^{-1}$ in Morrison (1971) and 100 larvae $1^{-1}$ in Huntington \& Miller (1989)]. In the present study, the sensitivity of Mytilus edulis larvae to hypoxia, measured in terms of shell length growth, increased with increasing body size. Growth of early prodissoconch larvae was maintained at $P_{\mathrm{O}_{2}} \geq 3.16 \mathrm{kPa}$, whereas growth of the later larval stage was significantly depressed at all the hypoxic levels examined. We have also demonstrated that differences in shell length are coupled to changes in organic content of the larvae; thus a reduction in shell growth reflects a depression in tissue growth under hypoxic conditions.

Our measurements of ingestion rates by Mytilus edulis larvae under normoxia gave a much lower value in comparison with other studies of feeding by mussel larvae (i.e. Riisgård et al. 1980, 1981, Jesperson \& Olsen 1982, Sprung 1984). For example, Sprung (1984) shows that 141 and $286 \mu \mathrm{m}$ (shell length) larvae ingest 57 and 316 cells of Isochrysis galbana per hour, respectively, at a food concentration of 20 cells $\mu l^{-1}$ and $12{ }^{\circ} \mathrm{C}$. The ingestion rates of similar larval sizes $(150,278 \mu \mathrm{m})$ measured in the present study were 23 and 154 cells $\mathrm{h}^{-1}$ at the corresponding cell concentration, but at $15^{\circ} \mathrm{C}$. The feeding activity of larvae measured in this study appeared to vary daily, especially in the $180 \mu \mathrm{m}$ larvae which were monitored over a period of $6 \mathrm{~d}$. Such a lower and variable ingestion rate was probably a consequence of the absence of a period of starvation prior to the measurement of feeding rate. An empty gut is known to enhance larval feeding rate (Sprung 1984, Gallager 1988).

In their response to hypoxia, early larval stages maintained or enhanced their feeding activity, whereas in the later stage $(278 \mu \mathrm{m})$, the feeding rate was depressed even at moderate $P_{\mathrm{O}_{2}}$ levels. The $P_{\mathrm{O}_{2}}$ at which feeding rate is reduced therefore increases with larval body size and this may reflect the size-dependent increase in the oxygen diffusion path and the concomitant reduction in metabolic rate under hypoxic conditions. Conversely, the larvae of Crassostrea virginica do not show evidence of enhanced feeding activity, but rather reduce their ingestion rate at all levels of hypoxia examined (from $6.0 \mathrm{kPa}$ down to $0.8 \mathrm{kPa}$ ). However, small larvae may still have relatively higher feeding rates than the pediveliger larvae (Widdows et al. 1989). Enhancement of feeding rate under hypoxia is also found in adult mussels (Bayne 1971), but the $P_{\mathrm{O}_{2}}$ at which maximum filtration (= ventilation) rate occurs is ca 12 to $16 \mathrm{kPa}$. Other adult bivalves such as Arctica islandica (Taylor \& Brand 1975) and Abra tenuis (Wang $\&$ Widdows unpubl.) also show a rise in ventilation as a compensatory response to declining $P_{\mathrm{O}_{2}}$, thus allowing more oxygen to be delivered per unit time. Measurement of rates of heat dissipation and oxygen uptake by mussel larvae in response to declining $P_{\mathrm{O}_{2}}$ highlights a similar size-dependent relationship as that found in $C$. virginica larvae (Widdows et al. 1989). However, the later larval stages of $M$. edulis appear to be more sensitive to hypoxia than the larvae of $C$. virginica. For example, the $P_{\mathrm{c}}$ values were $8 \mathrm{kPa}$ and $>8 \mathrm{kPa}$ for $C$. virginica and $M$. edulis respectively; and the $P_{\mathrm{O}_{2}}$ reducing heat dissipation to $50 \%$ of the normoxic rate were 2.3 and $6.1 \mathrm{kPa}$ for $C$. virginica and $M$. edulis respectively (Widdows et al. 1989). Nevertheless, results from oyster and mussel larvae suggest that earlier/smaller bivalve larval stages have a greater capacity to maintain their metabolic rate under conditions of decreasing $P_{\mathrm{O}_{2}}$, and the response of later stages is more typical of a 'metabolic conformer'. The ability of small prodissoconch larvae to extract oxygen from the surrounding water to meet their metabolic and respiratory requirements at low $P_{\mathrm{O}_{2}}$ values is likely to be a function of the higher surface-area-to-volume ratio, the short distance for oxygen diffusion and their relatively low oxygen demand. An increase in body size results in a reduction of surface-area-to-volume ratio and an increase in oxygen diffusion distance, which would consequently lead larvae to become more oxygen limited.

Recovery from anoxia shows that mussel larvae have a pattern of metabolic response similar to adult mussels (Widdows 1989) and the larvae of Crassostrea virginica (Widdows et al. 1989). Within the first hour of recovery there was an overshoot in the rates of heat dissipation and oxygen uptake and a reduction in the heat equivalent of oxygen uptake to $-219 \mathrm{~kJ} \mathrm{~mol}^{-1} \mathrm{O}_{2}$, followed by a gradual return towards the respective steady states within $3 \mathrm{~h}$. The overshoot in the oxygen uptake by larvae during the first hour of recovery was more pronounced than that in the adult mussels (Widdows \& Shick 1985, Shick et al. 1986, 1988, Widdows 1987), whereas overshoot in the rate of heat dissipation appeared to be comparable (ca $25 \%$ ). Widdows et al. (1989) suggest that reoxygenation of water within the shell valves of larvae may contribute to the overshoot in oxygen uptake (apparent oxygen debt payment) during the early aerobic recovery period (i.e. $30 \mathrm{~min}$ ), 
which also seems to be the case for mussel larvae. In adult mussels, after correcting for the reoxygenation of mantle cavity water and body fluid, the heat equivalent of net recovery oxygen uptake is $-252 \mathrm{~kJ} \mathrm{~mol}^{-1} \mathrm{O}_{2}$ (Shick et al. 1986), which is still significantly lower than the theoretical oxycaloric equivalent for aerobic catabolism. Consequently, there is a large conservation of heat in anabolic processes, such as the restoration of high-energy phosphate and the synthesis of glycogen from accumulated succinate during the early period of recovery from anoxia (Shick et al. 1988, Gnaiger, Shick $\&$ Widdows unpubl.).

Partitioning of total metabolic energy expenditure (TME) by the adult Mytilus edulis into maintenance, feeding and growth components (Widdows \& Hawkins 1989) provides a reference for interpreting the energetic basis of mussel larval response to hypoxia. The costs of digestion and absorption account for ca $17 \%$ of the TME and the costs of growth range between 0 and $30 \%$ of TME, depending upon the ingestion rate (Widdows \& Hawkins 1989). Changes in total energy expenditure by each larval stage in response to declining $P_{\mathrm{O}_{2}}$ also reflect the effect of hypoxia on each individual process (e.g. feeding, digestion and growth) and their related metabolic costs. For example, the maintenance of oxygen-independent heat dissipation by early prodissoconch larvae down to very low $P_{\mathrm{O}_{2}}$ levels $\left(P_{\mathrm{c}}=\right.$ $2.0 \mathrm{kPa}$ ) reflected the maintenance of larval growth and ingestion rates, whose costs represent a significant contribution to the total energy expenditure. Furthermore, the more oxygen-dependent energy metabolism by the later larval stages was accompanied by a suppression of costly processes such as feeding and growth at more moderate $P_{\mathrm{O}_{2}}$ levels $(<6 \mathrm{kPa})$.

Sprung \& Widdows (1986) measured the rates of heat dissipation by various larval stages of Mytilus edulis and found that 150 to $160 \mu \mathrm{m}$ larval size was a critical stage with respect to weight-specific metabolic rate. Beyond this size the mass-specific metabolic rate decreased exponentially ( $b=-0.23$ ) with increasing body size. Our measurements of the metabolic responses of mussel larvae to hypoxia also demonstrated a pronounced change occurring at this particular larval body size. Fig. 7 illustrated that larvae $\geq 155 \mu \mathrm{m}$ showed a more $P_{\mathrm{O}_{2}}$-dependent response; i.e. the metabolic rate was suppressed at moderate levels of hypoxia. In contrast, early prodissoconch larvae and $140 \mu \mathrm{m}$ larvae (single experiment, unpubl.) were able to maintain rates of heat dissipation down to $P_{\mathrm{O}_{2}}$ values as low as $2.0 \mathrm{kPa}$. Therefore a more $P_{\mathrm{O}_{2}}$-independent metabolic response to hypoxia was sustained in prodissoconch larvae until they developed to a critical larval size $(\leq 155 \mu \mathrm{m})$. It appears to coincide with the appearance of the prodissoconch II shell that may be a feature limiting oxygen diffusion and uptake, as well as the general reduction in surface-area-to-volume ratio. Larval growth experiments also suggested that ca 150 to $160 \mu \mathrm{m}$ was a critical size in terms of their response to hypoxia (Fig. 3, solid lines). As soon as larvae reached this size, shell growth rate was reduced at $P_{\mathrm{O}_{2}}$ levels of ca $5.91 \mathrm{kPa}$ and below. In contrast, there were no detectable effects of hypoxia on early prodissoconch shell growth, at least down to $1.38 \mathrm{kPa}$. Clearly, further information is required concerning larval growth and the nature of metabolism in response to long-term hypoxic exposure, particularly the physiological and biochemical changes occurring at the 150 to $160 \mu \mathrm{m}$ size.

In summary, the present study demonstrates the response of growth, feeding, oxygen uptake, and heat dissipation of mussel larvae to anoxia and various levels of hypoxia. It highlights the changes from the relatively oxygen-independent energy metabolism of early prodissoconch larvae to the more oxygen-dependent later larval stages. Furthermore, interpretation of physiological processes in relation to larval survival under hypoxia and anoxia stress indicates 2 different responses associated with larval developmental stages: (1) maintenance of swimming, feeding, metabolism and growth but with reduced survival by the younger/ smaller larval stage; and (2) suppression of energy metabolism, feeding and growth but with higher survival by the older/larger larvae. It supports the hypothesis that an increased tolerance to a range of environmental stressors is related to a controlled reduction in metabolic rate (Hoffmann \& Parson 1989). It suggests that hypoxia and anoxia will significantly influence the survival of larvae of Mytilus edulis, either directly or indirectly, through reduction in growth rate and thus prolongation of the pelagic phase, which due to the high mortality rate in the pelagic stage (e.g. $0.15 \mathrm{~d}^{-1}$; Jørgensen 1981), will significantly reduce the number of larvae surviving through to settlement and recruitment into the adult population (Widdows 1991).

Acknowledgements. This study was supported by a Chinese Educational Scholarship awarded to W. X. Wang. We are grateful to the referees for valuable comments on the manuscript.

\section{LITERATURE CITED}

Bayne, B. L. (1971). Ventilation, the heart beat and oxygen uptake by Mytilus edulis L. in declining oxygen tension. Comp. Biochem. Physiol. 40A: 1065-1085

Bayne, B. L. (1975). Aspects of physiological condition in Mytilus edulis L., with special reference to the effects of oxygen tension and salinity. In: Barnes, H. (ed.) Proc. 9th Eur. Mar. Biol. Symp. Aberdeen University Press, Aberdeen, p. 213-238 
Bayne, B. L. (1976). The biology of mussel larvae. In: Bayne, B. L. (ed.) Marine mussels: their ecology and physiology. Cambridge University Press, Cambridge, p. 81-120

Bayne, B. L. (1983). Physiological ecology of marine molluscan larvae. In: Verdonk, N. H., Van den Biggelaar, J. A. M., Tompa, A. (eds.) The Mollusca, Vol. III. Academic Press, New York, p. 299-343

Bayne, B. L., Newell, R. C. (1983). Physiological energetics of marine molluscs. In: Wilbur, K. M., Saleuddin, A. S. M. (eds.) The Mollusca, Vol. IV, Part 1. Academic Press, New York, p. 407-515

Brockmann, U., Billen, G., Gieskes, W. W. C. (1988). North Sea nutrients and eutrophication. In: Salomons, W., Bayne, B. L., Duursma, E. K., Forstner, U. (eds.) Pollution of the North Sea: an assessment. Springer-Verlag, Berlin, p. 348-389

Cragg, S. M. (1980). Swimming behaviour of the larvae of Pecten maximus (L.) (Bivalvia). J. mar. biol. Ass. U.K. 60: 551-564

Degobbis, D. (1989). Increased eutrophication of the Northern Adriatic Sea: second act. Mar. Pollut. Bull. 20: 452-457

Eyster, L. S., Pechenik, J. A. (1987). Attachment of Mytilus edulis L. larvae on algal and byssal filaments is enhanced by water agitation. J. exp. mar. Biol. Ecol. 114: 99-110

Famme, P., Knudsen, J., Hansen, E. S. (1981). The effect of oxygen on the aerobic-anaerobic metabolism of the marine bivalve, Mytilus edulis. Mar. Biol. Lett. 2: 345-351

Gabbott, P. A. (1976). Energy metabolism. In: Bayne, B. L. (ed.) Marine mussels: their ecology and physiology. Cambridge University Press, Cambridge, p. 293-355

Gallager, S. M. (1988). Visual observations of particle manipulation during feeding in larvae of a bivalve molluscs. Bull. mar. Sci. 43: 344-365

Gnaiger, E. (1983). Heat dissipation and energetic efficiency in animal anoxibiosis: economy contra power. J. exp. Zool. 228: $471-490$

Herreid, C. F. (1980). Hypoxia in invertebrates Comp. Biochem. Physiol. 67 A: 311-320

Hoffmann, A. A., Parsons, P. A. (1989). An integrated approach to environmental stress tolerance and life history variation: dessication tolerance in Drosophila. Biol. J. Linn. Soc. 37: $117-136$

Huntington, K. M., Miller, D. C. (1989). Effects of suspended sediment, hypoxia, and hyperoxia on larval Mercenaria mercenaria (Linnaeus, 1758). J. Shellfish Res. 8: 37-42

Jespersen, H., Olsen, K. (1982). Bioenergetics in veliger larvae of Mytilus edulis L. Ophelia 21: 101-113

Jorgensen, C. B. (1981). Mortality, growth and grazing impact of a cohort of bivalve larvae, Mytilus edulis L. Ophelia 20 : 185-192

Mileikovsky, S. A. (1971). Types of larval development in marine bottom invertebrates, their distribution and ecological significance: a re-evaluation. Mar. Biol. 10: 193-213

Morrison, G. (1971). Dissolved oxygen requirements for embryonic and larval development of the hardshell clam, Mercenaria mercenaria. J. Fish. Res. Bd Can. 28: 379-381

Pechenik, J. A., Eyster, L. S., Widdows, J. , Bayne, B. L. (1990). The influence of food concentration and temperature on growth and morphological differentiation of blue mussel Mytilus edulis L. larvae. J. exp. mar. Biol. Ecol. 136: 47-64

Riisgărd, H. U., Randløv, A., Hamburger, K. (1981). Oxygen

This article was submitted to the editor consumption and clearance as a function of size in Mytilus edulis L. veliger larvae. Ophelia 20: 179-183

Riisgård, H. U., Randløv, A., Kristensen, P. S. (1980). Rates of water processing, oxygen consumption and efficiency of particle retention in veligers and young post-metamorphic Mytilus edulis. Ophelia 19: $37-47$

Rosenberg, R., Loo, L. O. (1988). Marine eutrophication induced oxygen deficiency: effects on soft bottom fauna, Western Sweden. Ophelia 29: 213-225

Shick, J. M., Gnaiger, E., Widdows, J., Bayne, B. L., de Zwaan, A. (1986). Activity and metabolism in the mussel Mytilus edulis L. during intertidal hypoxia and aerobic recovery. Physiol. Zool. 59: 627-642

Shick, J. M., Widdows, J., Gnaiger, E. (1988). Calorimetric studies of behaviour, metabolism and energetics of sessile intertidal animals. Am. Zool. 28: 161-181

Sprung, M. (1984). Physiological energetics of mussel larvae (Mytilus edulis). II. Food uptake. Mar. Ecol. Prog. Ser. 17: 295-305

Sprung, M., Widdows, J. (1986). Rate of heat dissipation by gametes and larval stages of Mytilus edulis. Mar. Biol. 91: $41-45$

Thorson, G. (1950). Reproduction and larval ecology of marine bottom invertebrates. Biol. Rev. 25: 1-45

Taylor, A. C., Brand, A. R. (1975). A comparative study of the respiratory responses of the bivalves Arctica islandica (L.) and Mytilus edulis L. to declining oxygen tension. Proc. R. Soc. Lond. B. 190: 443-456

Widdows, J. (1987). Application of calorimetric methods in ecological studies. In: James, A. M. (ed.) Thermal and energetic studies and cellular biological systems. Wright, Bristol, p. 182-215

Widdows, J. (1989). Calorimetric and energetic studies of marine bivalves. In: Wieser, W., Gnaiger, E. (eds.) Energy transformations in cells and organisms. Georg Thieme Verlag, Stuttgart, New York, p. 145-154

Widdows, J. (1991). Physiological ecology of mussel larvae. Aquaculture (in press)

Widdows, J., Hawkins, A. J. S. (1989). Partitioning of rate of heat dissipation by Mytilus edulis into maintenance, feeding and growth components. Physiol. Zool. 62: 764-784

Widdows, J., Newell, R. I. E., Mann, R. (1989). Effects of hypoxia and anoxia on survival, energy metabolism and feeding of oyster larvae (Crassostrea virginica, Gmelin). Biol. Bull. mar. biol. Lab., Woods Hole 177: 154-166

Widdows, J., Shick, J. M. (1985). Physiological responses of Mytilus edulis and Cardium edule to aerial exposure. Mar. Biol. 85: 217--232

Wright, D. A., Phillips, D. J. H. (1988). Chesapeake and San Francisco Bays: a study in contrasts and parallels. Mar. Pollut. Bull. 19: 405-413

Zwaan, A. de (1983). Carbohydrate catabolism in bivalve. In: Hochachka, P. W (ed.) The Mollusca, Vol. 1, Metabolic biochemistry and molecular biomechanics. Academic Press, New York, p. 137-175

Zwaan, A. de, Putzer, V (1985). Metabolic adaptations of intertidal invertebrates to environmental hypoxia (a comparison of environmental anoxia to exercise anoxia). In: Laverick, M. S. (ed.) Physiological adaptation of marine animals. Symp. Soc. exp. Biol. XXXIX, p. 33-62

Manuscript first received: October 16, 1990

Revised version accepted: January 16, 1991 